\title{
Heme effects of hemin on growth of peridontopathogens
}

\author{
Hyun-Jun Yoo', Sung-Hoon Lee ${ }^{2 *}$ \\ 'Department of Preventive Dentistry, College of Dentistry, Dankook University, Cheonan, Republic of Korea \\ ${ }^{2}$ Department of Oral Microbiology and Immunology, College of Dentistry, Dankook University, Cheonan, Republic of Korea
}

Purpose: The purpose of this study was to investigate effect of heme on periodontopathogens. Materials and Methods: The experiment was performed using 7 types of anaerobic bacteria present in the periodontal pocket. The bacteria were cultured using suitable medium in an anaerobic condition with or without hemin, and the growth of the bacteria was measured every 6 hours by a spectrophotometer. Results: the growth of Porphyromonas gingivalis was different only by the presence or absence of hemin. The growth of other periodontopathogens except Treponema denticola was different in a hemin concentration-dependent manner. The growth of $T$. denticola was interfered by hemin. Conclusion: Heme may be a factor that leads dysbiosis in the microbial ecosystem of the subgingival plaque and thereby promote a periodontitis-causing environment. (J Dent Rehabil Appl Sci 2021;37(1):31-8)

Key words: hemin; periodontopathogen; dysbiosis; growth

\section{Introduction}

Periodontal disease is an inflammatory disease in oral cavity and related with gram-negative anaerobic bacteria. ${ }^{1}$ In the 19th century, Socranskii group reported that Porphyromonas gingivalis, Tannerella forsythia (formerly Bacteroides forsythus), and Treponema denticola are closely related with periodontitis by epidemiological study. ${ }^{2}$ After these results, the researchers studied the virulence factors associated with periodontitis in each bacterium. ${ }^{3}$ Recently, ecological plaque hypothesis was raised, by which the studies on periodontitis-related bacteria have also changed a lot. ${ }^{4}$ According to this hypothesis, the induction of periodontitis is related with dysbiosis of periodontal pocket. In healthy people, microbial ecosystem is balanced by Gram-positive facultative anaerobes like normal flora. However, the microbial ecosystem

*Correspondence to: Sung-Hoon Lee

Assistant Professor, Department of Oral Microbiology and Immunology, College of Dentistry, Dankook University, 119 Dandae-ro, Dongnam-gu, Cheonan, 31116 Republic of Korea

Tel: +82-41-550-1868, Fax: +82-41-550-1859, E-mail: dennisyi@dankook.ac.kr

Received: March 3, 2021/Last Revision: March 4, 2021/Accepted: March 4, 2021 is broken by changes in external or oral environment, and because of this, the number of Gramnegative obligated anaerobes is increased. Eventually, multi-species pathogens may induce periodontitis. Therefore, the studies on effects of complex bacteria rather than single-species bacteria in periodontitis are being investigated. ${ }^{5}$ Regarding changes in the oral environment, A study was recently reported that gingipain of $P$. gingivalis induces initial inflammation and increases the influx of gingival crevicular fluid into gingival pocket. ${ }^{6}$ These symptoms can be expected to increase the proportion of Gram-negative obligated anaerobes.

Heme consists of a tetrapyrrole ring with an iron atom in center. Also, heme is linked specific protein such as hemoglobin, myoglobin, hemopexin, albumin and cytochromes, ${ }^{7,8}$ and reversible binds oxygen and transport electrons in human body. Further-

CopyrightC 2021 The Korean Academy of Stomatognathic Function and Occlusion. (c) It is identical to Creative Commons Non-Commercial License. 
more, heme is a damage-associated molecular pattern (DAMP) and triggers inflammatory responses of immune cells. ${ }^{9}$ Iron is found in the form of heme ${ }^{10}$ and a source for bacterial growth. ${ }^{11}$ Periodontitis-related bacteria are also used iron for metabolism, toxicity, and pathogenesis. ${ }^{12-15}$ In a clinical study, when hemin concentration between healthy and periodontal disease site was compared, the heme in healthy site and the disease site showed range of $0-251 \mathrm{nM}$ and 0 - $7723.5 \mathrm{nM}$, respectively. ${ }^{16}$ This data makes that it possible to investigate the effects of hemin on relation with periodontitis. However, the effect of hemin on bacterial growth in periodontal pocket has not been reported.

In this study, the bacteria related with periodontitis was investigated growth in various concentration of hemin.

\section{Materials and Methods}

In this study, Filifactor alocis ATCC 35896, Fusobacterium nucleatum ATCC 25586, Porphyromonas gingivalis ATCC 33277, Prevotella intermedia ATCC 25611, Prevotella nigrescens ATCC 33563, Tannerella forsythia ATCC 43037, and Treponema denticola ATCC 35405 were used to investigate effect of hemin. For cultivation of periodontitis-related pathogens, F. alocis was used columbia broth supplemented with yeast extract, L-cysteine $(0.2 \%)$, L-arginine $(0.4 \%)$, hemin $(5 \mu \mathrm{g} / \mathrm{ml})$, and vitamin $\mathrm{K}(0.2 \mu \mathrm{g} / \mathrm{ml})$. T. forsythia was used modified NOS medium supplemented with Nacetylmuramic acid $(0.1 \mu \mathrm{g} / \mathrm{ml})$, vitamin $\mathrm{K}(0.2 \mu \mathrm{g} /$ $\mathrm{ml})$, hemin $(5 \mu \mathrm{g} / \mathrm{ml})$, and fetal bovine serum (4\%). T. denticola was used GYGVS medium. F. nucleatum, P. gingivalis, $P$. intermedia, and $P$. nigrescens were used brain heart infusion broth supplemented with hemin $(5 \mu \mathrm{g} /$ $\mathrm{ml})$ and vitamin $\mathrm{K}(0.2 \mu \mathrm{g} / \mathrm{ml})$. The bacteria were cultured at $37^{\circ} \mathrm{C}$ in anaerobic condition $\left(\mathrm{H}_{2} 5 \%, \mathrm{CO}_{2}\right.$ $10 \%$, and $\mathrm{N}_{2} 85 \%$ )

Hemin was purchased from sigmaaldrich and extracted from bovine. Hemin stock solutions were prepared in three concentrations as $0.5,5$, and 50 $\mathrm{mg} / \mathrm{ml} .5,50$ and $500 \mathrm{mg}$ of hemin were completely dissolved with $0.1,0.5$, and $1 \mathrm{ml}$ of $1 \mathrm{~N} \mathrm{NaOH}$ in conical tube (SPL LifeSciences, Pocheon, Korea), respectively, and distilled water was then filled onto $10 \mathrm{ml}$. The prepared solution was filtered with polyvinylidene fluoride (PVDF) filter $(0.22 \mu \mathrm{m}$ of pore size). The stock solution was stored in anaerobic chamber before use.

Each cultured bacterium was harvested by centrifugation at $5,000 \times \mathrm{g}$ for $10 \mathrm{~min}$, and fresh medium without hemin was added after removing supernatant. The bacteria were counted with bacterial counting chamber (and adjusted with fresh medium without hemin at $1 \times 10^{7}$ cells $/ \mathrm{ml}$. Each medium without hemin $(9 \mathrm{ml})$ was added hemin at final concentration of $0.5,5,50$ and $500 \mu \mathrm{g} / \mathrm{ml}$ using the stock solution, and then the prepared bacteria were inoculated in the medium. The bacterial growth was measured every 6 hours by optical density using a spectrophotometer at $660 \mathrm{~nm}$ of wavelength.

Statistical analysis was performed by IBM SPSS statistics ver. 23 software (IBM, Armonk, USA). The data from the different groups was analyzed by the non-parametric Kruskal-Wallis test. Statistical significance was defined by $P$ value of less than 0.05 . All data are expressed as the median and interquartile range.

\section{Results}

When P. gingivalis was cultured BHI broth including vitamin $\mathrm{K}$ with various concentration of hemin, the growth of $P$. gingivalis did not showed significant difference in the condition with hemin (Fig. 1), and in hemin free condition, $P$. gingivalis growth was showed slower. The growth of $P$. gingivalis entered the exponential phase after 12 hours, and reached the stationary phase after 36 hours in all concentration of hemin.

P. nigrescens grew the fastest at 50 and $100 \mu \mathrm{g} / \mathrm{ml}$ of hemin condition, and the growth ratio of $P$. nigrescens was changed in a dose-dependent manner of hemin (Fig. 2). Furthermore, the stationary phase of $P$. nigrescens growth showed different concentration by hemin concentration. In case of $P$. nigrescens, the its growth reached the stationary phase after 42 hours, and $P$. nigrescens cultured at 0 and $0.5 \mu \mathrm{g} / \mathrm{ml}$ of hemin did not reach stationary phase. 


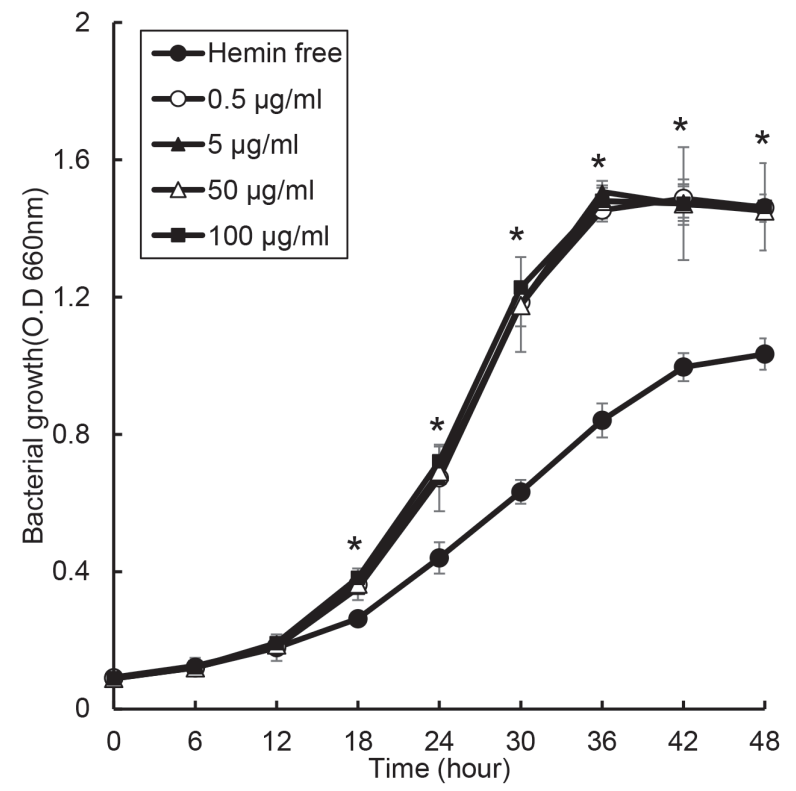

Fig. 1. Effect of hemin concentration on the growth of $P$. gingivalis. $P$. gingivalis was cultured with various concentration of hemin or without hemin. Asterisk $(*)$ indicates statistically significant differences compared with hemin free $(P<0.05)$.

The growth of $P$. intermedia was changed by hemin concentration (Fig. 3). In the condition of 50 and $100 \mu \mathrm{g} / \mathrm{ml}$ of hemin, the growth curve showed typical S shape such as log, exponential, and stationary phase. P. intermedia entered stationary phase after 36 hours in 50 and $100 \mu \mathrm{g} / \mathrm{ml}$ of hemin and after 42 hours in $5 \mu \mathrm{g} / \mathrm{ml}$ of hemin.

F. nucleatum slowly grew at $0.5 \mu \mathrm{g} / \mathrm{ml}$ of hemin and hemin free condition. and the growth ratio of F. nucleatum was changed in a dose-dependent manner of hemin (Fig. 4). F. nucleatum entered stationary phase after 36 hours in 50 and $100 \mu \mathrm{g} / \mathrm{ml}$ of hemin and after 48 hours in $5 \mu \mathrm{g} / \mathrm{ml}$ of hemin.

F. alocis entered stationary phase between 30 and 36 $\mathrm{h}$ after inoculation into fresh medium at 50 and 100 $\mu \mathrm{g} / \mathrm{ml}$ of hemin (Fig. 5). F. alocis slowly grew under $5 \mu \mathrm{g} / \mathrm{ml}$ of hemin and did not showed stationary phase to 48 hours. Up concentration of $50 \mu \mathrm{g} / \mathrm{ml}$ of hemin, the growth of F. alocis entered exponential phase after 12 hours and reached stationary phase after 36 hours.

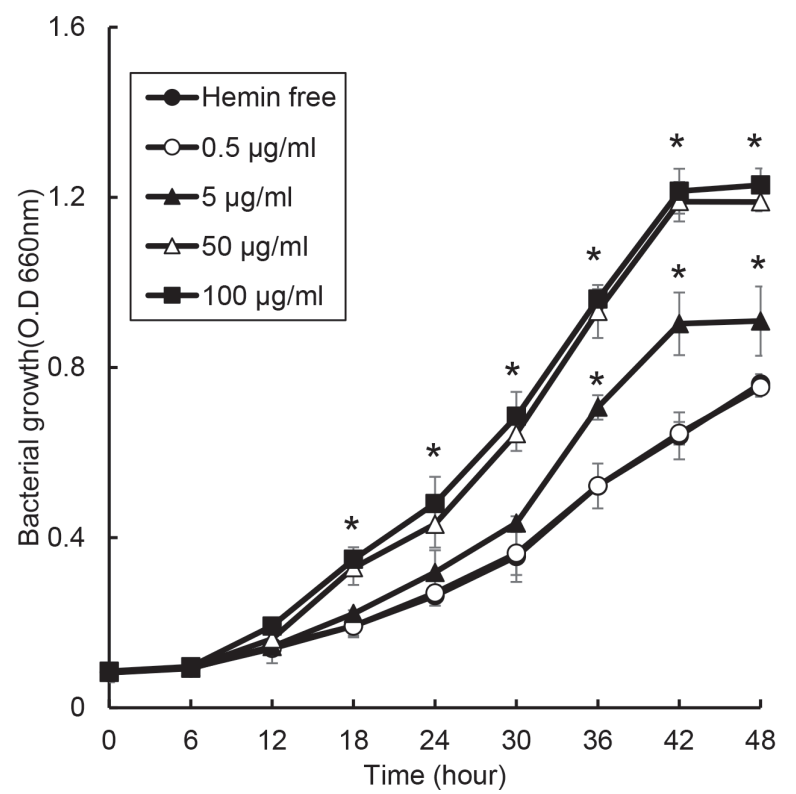

Fig. 2. Effect of hemin concentration on the growth of $P$. nigrescens. P. nigrescens was cultured with various concentration of hemin or without hemin. Asterisk $\left({ }^{*}\right)$ indicates statistically significant differences compared with hemin free $(P<0.05)$.

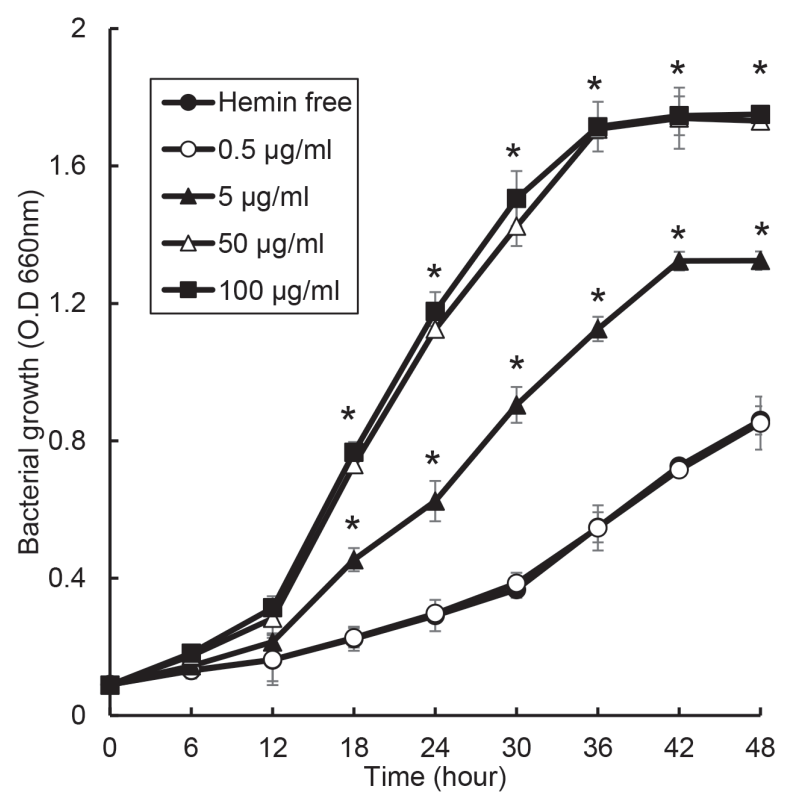

Fig. 3. Effect of hemin concentration on the growth of P. intermedia. P. intermedia was cultured with various concentration of hemin or without hemin. Asterisk (*) indicates statistically significant differences compared with hemin free $(P<0.05)$. 


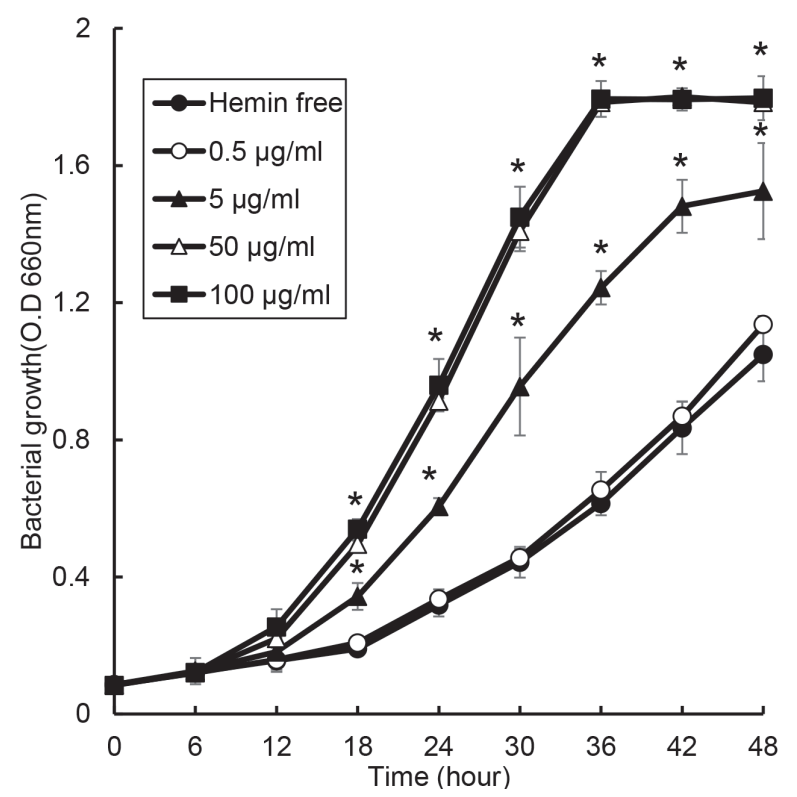

Fig. 4. Effect of hemin concentration on the growth of F. nucleatum. F. nucleatum was cultured with various concentration of hemin or without hemin. Asterisk (*) indicates statistically significant differences compared with hemin free $(P<0.05)$.

T. forsythia slowly grew under concentration of $5 \mu$ $\mathrm{g} / \mathrm{ml}$ of hemin as shown Fig. 6. The growth of $T$. forsythia entered exponential phase between 6 and 12 hours and reached stationary phase after 36 hours in 50 and $100 \mu \mathrm{g} / \mathrm{ml}$ of hemin condition. Especially, comparing 50 and $5 \mu \mathrm{g} / \mathrm{ml}$ of hemin condition, the growth of T. forsythia was the same time to reach stationary phase. However, the bacterial concentration was different.

The growth of $T$. denticola was not affect to $50 \mu$ $\mathrm{g} / \mathrm{ml}$ of hemin concentration. Unlike other bacteria, the growth rate of $T$. denticola decreased at a concentration of $100 \mu \mathrm{g} / \mathrm{ml}$ of hemin (Fig. 7). At all concentration of hemin, the growth of $T$. denticola did not reach stationary phase util 48 hours.

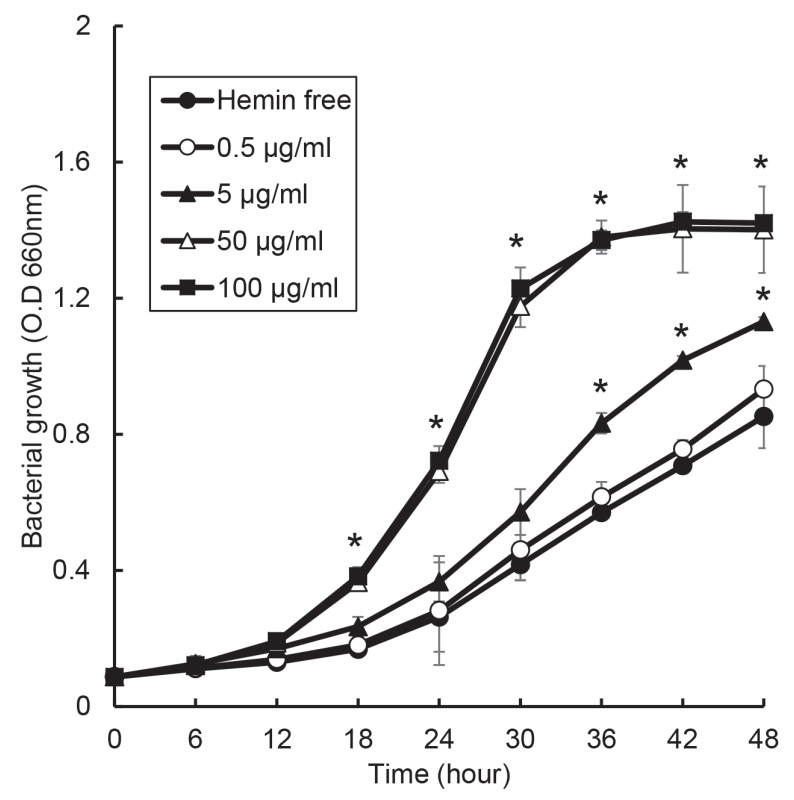

Fig. 5. Effect of hemin concentration on the growth of $F$. alocis. F. alocis was cultured with various concentration of hemin or without hemin. Asterisk $\left({ }^{*}\right)$ indicates statistically significant differences compared with hemin free $(P$ $<0.05)$.

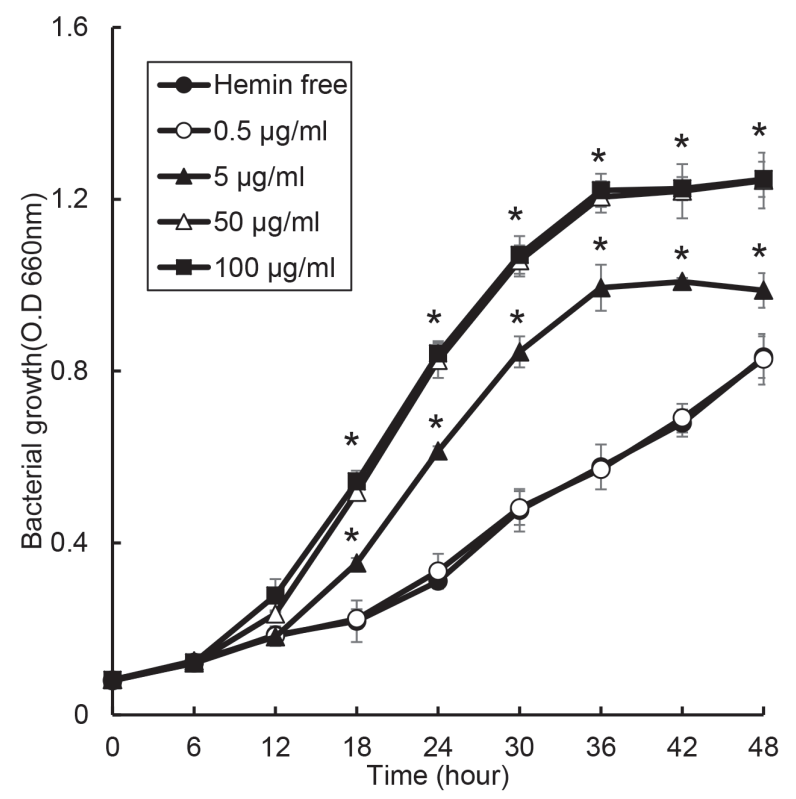

Fig. 6. Effect of hemin concentration on the growth of $T$. forsythia. T. forsythia was cultured with various concentration of hemin or without hemin. Asterisk (*) indicates statistically significant differences compared with hemin free $(P<0.05)$. 


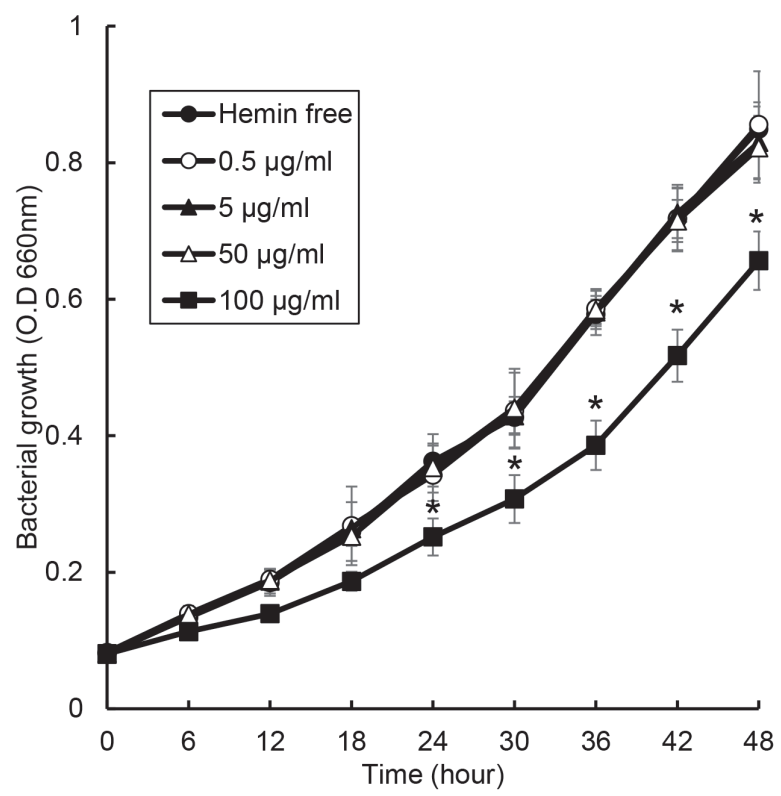

Fig. 7. Effect of hemin concentration on the growth of $T$. denticola. T. denticola was cultured with various concentration of hemin or without hemin. Asterisk $\left({ }^{*}\right)$ indicates statistically significant differences compared with hemin free $(P<0.05)$.

\section{Discussion}

In relation of the outbreak of periodontitis, the type of bacteria is previously considered more important, but in recent years, not only the type of bacteria but also the number of total bacteria is considered important. In the 1970s, a specific plaque hypothesis was suggested that specific bacteria were associated with periodontitis, ${ }^{17}$ and later, Socranskii group suggested P. gingivalis, T. forsythia, and T. denticola as periodontitis-causing bacteria. ${ }^{18}$ Philip D. March proposed ecological plaque hypothesis that combined specific pathogens and bacterial composition. ${ }^{4}$ This hypothesis is that oral diseases are the result of an imbalance in the total microflora due to ecological stress, resulting in an enrichment of oral pathogens as periodontitis related bacteria. Also, according to the recent "The Keystone-Pathogen Hypothesis", $P$. gingivalis induces initial inflammation of periodontal tissue using gingipain. ${ }^{6}$ The initial inflammation increases the influx of gingival crevicular fluid (GCF) into the periodontal pocket and causes dysbiosis in the microbial ecosystem. Therefore, this study was first examined the effect of hemin as a component of GCF on the growth of periodontitis-related bacteria to investigate the factors related to the dysbiosis.

The growth of $P$. gingivalis was not significantly changed by hemin concentration although the growth was slower in hemin free condition. Except for $T$. denticola, the growth of anaerobic bacteria present in other periodontal pocket was found to be rapid at certain hemin concentration. In most studies, when cultivating periodontitis-related bacteria, the concentration of hemin is $5 \mu \mathrm{g} / \mathrm{ml}$. ${ }^{19-21}$ This concentration is not the best condition for the growth of periodontopathogens. When predicted based on the experimental results, it was found that periodontopathogens grow best at least $50 \mu \mathrm{g} / \mathrm{ml}$ of hemin. In case of $P$. gingivalis, the optimal condition was when the hemin concentration was $5 \mu \mathrm{g} / \mathrm{ml}$ or higher. Unlike other bacteria, $P$. gingivalis grew well in low concentration of hemin. In clinical study about measurement of hemin concentration, the average hemin concentration is $46.6 \mathrm{nM}$ in healthy sites and 1116.6 $\mathrm{nM}$ in diseased sites. ${ }^{16}$ Based on this clinical study and the results, it is possible to explain "The Keystone pathogen hypothesis" and "Ecological plaque hypothesis". P. gingivalis induced initial inflammation, by which GCF is flowed into periodontal pocket and heme concentration may be increased. This elevated heme condition may promote the growth of other periodontopathogens. The heme is a factor that cause dysbiosis in the microbial ecosystem of the periodontal pocket. Eventually, the rapid growth of the bacteria related to periodontitis occupies a large part in the microbial ecosystem and induces periodontitis.

Recently, ecological plaque hypothesis has been recognized as the theory regarding the occurrence of periodontitis. Although it is known that dysbiosis in periodontal pocket occurs due to the influx of GCF, there is little information about which factors cause the dysbiosis. 


\section{Conclusion}

The present study showed that periodontopathogens rapidly grow above a specific concentration of hemin. Eventually, heme may be a factor that leads dysbiosis in the microbial ecosystem of the subgingival plaque and thereby promote a periodontitiscausing environment. The further study will be necessary to investigate the change in virulence of periodontopathogens caused by changes in hemin concentration.

\section{ORCID}

Hyun-Jun Yoo https://orcid.org/0000-0002-01008309

Sung-Hoon Lee https://orcid.org/0000-0002-88520419

\section{References}

1. Dahlén GG. Black-pigmented gram-negative anaerobes in periodontitis. FEMS Immunol Med Microbiol 1993;6:181-92.

2. Socransky SS. Microbiology of periodontal disease - present status and future considerations. J Periodontol 1977;48:497-504.

3. O'Brien-Simpson NM, Veith PD, Dashper SG, Reynolds EC. Antigens of bacteria associated with periodontitis. Periodontol 2000 2004;35:101-34.

4. Marsh PD. Microbial ecology of dental plaque and its significance in health and disease. Adv Dent Res 1994;8:263-71.

5. Listgarten MA. The role of dental plaque in gingivitis and periodontitis. J Clin Periodontol 1988;15: 485-7.

6. Hajishengallis G, Darveau RP, Curtis MA. The keystone-pathogen hypothesis. Nat Rev Microbiol 2012;10:717-25.

7. Wijnsma KL, Veissi ST, de Wijs S, van der Velden T, Volokhina EB, Wagener FADTG, van de Kar NCAJ, van den Heuvel LP. Heme as Possible Contributing Factor in the Evolvement of Shiga-Toxin Escherichia coli Induced Hemolytic-Uremic Syndrome. Front Immunol 2020;11:547406.
8. Muller-Eberhard U, Fraig M. Bioactivity of heme and its containment. Am J Hematol 1993;42:59-62.

9. Chaudhry SR, Hafez A, Rezai Jahromi B, Kinfe TM, Lamprecht A, Niemela M, Muhammad S. Role of Damage Associated Molecular Pattern Molecules (DAMPs) in Aneurysmal Subarachnoid Hemorrhage (aSAH). Int J Mol Sci 2018;19:2035.

10. Liu X, Olczak T, Guo HC, Dixon DW, Genco CA. Identification of amino acid residues involved in heme binding and hemoprotein utilization in the Porphyromonas gingivalis heme receptor HmuR. Infect Immun 2006;74:1222-32.

11. Rouault TA. Microbiology. Pathogenic bacteria prefer heme. Science 2004;305:1577-8.

12. Al-Qutub MN, Braham PH, Karimi-Naser LM, Liu X, Genco CA, Darveau RP. Hemin-dependent modulation of the lipid A structure of Porphyromonas gingivalis lipopolysaccharide. Infect Immun 2006;74:4474-85.

13. Lee HR, Rhyu IC, Kim HD, Jun HK, Min BM, Lee $\mathrm{SH}$, Choi BK. In-vivo-induced antigenic determinants of Fusobacterium nucleatum subsp. nucleatum. Mol Oral Microbiol 2011;26:164-72.

14. Yu F, Anaya C, Lewis JP. Outer membrane proteome of Prevotella intermedia 17: identification of thioredoxin and iron-repressible hemin uptake loci. Proteomics 2007;7:403-12.

15. Aguilera O, Andrés MT, Heath J, Fierro JF, Douglas CW. Evaluation of the antimicrobial effect of lactoferrin on Porphyromonas gingivalis, Prevotella intermedia and Prevotella nigrescens. FEMS Immunol Med Microbiol 1998;21:29-36.

16. Liu LY, McGreor N, Wong BK, Butt H, Darby IB. The association between clinical periodontal parameters and free haem concentration within the gingival crevicular fluid: a pilot study. J Periodontal Res 2016;51:86-94.

17. Loesche WJ. Chemotherapy of dental plaque infections. Oral Sci Rev 1976;9:65-107.

18. Socransky SS, Haffajee AD, Cugini MA, Smith C, Kent RL Jr. Microbial complexes in subgingival plaque. J Clin Periodontol 1998;25:134-44.

19. Olczak T, Simpson W, Liu X, Genco CA. Iron and heme utilization in Porphyromonas gingivalis. FEMS Microbiol Rev 2005;29:119-44. 
20. Lee SH, Baek DH. Effects of Streptococcus thermophilus on volatile sulfur compounds produced by Porphyromonas gingivalis. Arch Oral Biol 2014; 59:1205-10.

21. Lee SH, Baek DH. Characteristics of Porphyromonas gingivalis lipopolysaccharide in co-culture with Fusobacterium nucleatum. Mol Oral Microbiol 2013;28:230-8. 


\section{치주병원균의 성장에서의 heme의 영향}

유현준 ${ }^{1}$ 조교수, 이성훈 ${ }^{2 *}$ 조교수

${ }^{1}$ 단국대학교 치과대학 예방치의학교실

${ }^{2}$ 단국대학교 치과대학 구강미생물학교실

목적: 이 연구의 목적은 치주병원균에 대한 헴의 영향을 살펴보기 위함이다.

연구 재료 및 방법: 치주낭에 존재하는 7종의 혐기성세균을 이용하여 실험을 진행하였다. 세균을 혐기환경에서 배지를 이 용하여 hemin의 있고 없음으로 하여 배양을 하였다. 세균의 성장은 매 6시간마다 분광광도계를 이용하여 측정하였다.

결과: 헤민의 존재여부에 따른 성장의 차이는 Porphyromonas gingivalis에서만 관찰되었다. Treponema denticola를 제외한 치 주병원균의 성장은 헤민의 농도에 의존적인 것으로 관찰되었다. T. denticola의 성장은 헤민에 의해 방해를 받았다.

결론: 헴은 치은연하 치태의 미생물 생태계에서 미생물분포의 불균형을 유도하여 치주염을 유발하는 환경을 조장할 것 이다.

(구강회복응용과학지 2021;37(1):31-8)

주요어: 헴; 치주염세균; 성장; 세균불균형 